\title{
Analysis of health, functioning and disability of rural inhabitants aged 60-80 living in south-eastern Poland - a cross sectional study
}

\author{
Agnieszka Ćwirlej-Sozańska', Anna Wilmowska-Pietruszyńska', Agnieszka Wiśniowska-Szurlej', \\ Bernard Sozański² \\ 1 Institute of Physiotherapy, Faculty of Medicine, University of Rzeszow, Poland \\ ${ }^{2}$ Centre for Innovative Research in Medical and Natural Sciences, Medical Faculty, University of Rzeszow, Poland
}

Ćwirlej-Sozańska A, Wilmowska-Pietruszyńska A, Wiśniowska-Szurlej A, Sozański B. Analysis of health, functioning and disability of rural inhabitants aged 60-80 living in south-eastern Poland - a cross sectional study. Ann Agric Environ Med. 2018; 25(3): 388-394. doi: 10.5604/12321966.1235175

\begin{abstract}
Introduction. Since the beginning of the $20^{\text {th }}$ century, the aging of the European population has been observed, and the potential long-term social and economic problems have been flagged.

Objective. The aim of the study was assessment of the level of disability and multidimensional analysis of determining factors among the elderly living in rural areas.

Materials and method. The study was conducted in a population of 973 people aged $60-80$ living in south-eastern Poland. The research tool used in the study was the WHO Disability Assessment Schedule - WHODAS 2.0.

Result. As many as $28.26 \%$ of the study group had at least a moderate level of disability; severe disability was observed in $11.51 \%$ of the participants, and extreme disability was experienced by $0.21 \%$. The highest average level of disability in the study group was found in performing activities of daily living (mean $=28.94 ; S D=30.04$ ), participation in everyday life (mean = 28.40; SD = 23.29) and mobility (mean = 26.04; SD = 27.57). Statistically significant relationships were observed between age, gender, education level, physical activity and number of chronic diseases.

Conclusion. An increase in the level of education and popularization of physical activity may be helpful in reducing the prevalence of disability among the elderly inhabitants of rural areas. Increasing access to health care, aimed at rapid diagnosis of chronic diseases, treatment and rehabilitation, seems to be a reasonable action preventing the disability in rural areas.
\end{abstract}

\section{Key words}

disabled persons, aged, rural population, socio-economic factors, male, female

\section{INTRODUCTION}

As a result of progressive demographic changes, involving the rapid aging of the population, a significantly increased interest has evolved in the health and functioning of the elderly worldwide. Of particular concern is the activity and participation of older people in daily family and social life. In 2001, the concepts concerning these activities and participation were introduced by the World Health Organization (WHO), and the International Classification of Functioning, Disability and Health (ICF) developed [1]. This forms the basis for the biopsychosocial model of health. An activity descriptor is defined as a task or action performed by an individual, whereas participation is the involvement of a person in everyday life situations [1]. In recent years, the socio-economic models of health behaviour have attracted the increasing attention of researchers around the world [2]. Activity and participation are now considered to be particularly important health determinants affecting the wellbeing of older people $[3,4]$. Older people highly involved in social and recreational activities present [5], better mood, higher self-esteem, identity and good self-assessment of their health [6]. According to Cohen, extensive social relationships influences the improvement of psychological well-being by increasing a community affiliation and reducing the risk of

Address for correspondence: Agnieszka Ćwirlej-Sozańska, Institute of Physiotherapy, Faculty of Medicine, University of Rzeszow

E-mail: sozanska@ur.edu.pl

Received: 14 January 2017; accepted: 6 February 2017; first published on April 2017 depression [7]. Smith and Christakis found that positive social relationships have a positive effect on improving the health behaviour of the elderly [8]. Social relations may increase the level of physical activity, and the consumption of fruit and vegetables [9]. Bot et al. suggest that the elderly living in a larger and denser social network have a healthier lifestyle [10]. Dickens et al., in a systematic review, have indicated that the activities carried out in groups counteract social exclusion [11], which is closely linked with an increased risk of limiting functional autonomy [12] and death [13]. In the elderly population, the prevalence of chronic diseases increases [14]. A consequence of multiple-diseases is represented by the difficulty in performing basic and complex activities of daily living (ADL and IADL) [15]. In aging societies, the syndrome of weakness and its complications are on the increase [16]. The increasing incidence of disability in the performance of activities of daily living, [17], has an impact on the lives of older people, their families, whole communities, as well as on the functioning of the health care system and social service $[18,19]$.

Despite the attempts (undertaken for several years) focused on the wider improvement of living conditions and access to various goods and services of rural residents in Poland, significant disproportions still exist between life in the countryside and in the city. Access to education, health and social care, culture, etc. is lower and generally at a poorer level, compared to urban areas. Due to the increase in availability of transport services and; therefore, greater mobility, young people from rural areas have 
greater possibilities to equal their opportunities in many areas of life. However, the situation of older inhabitants of rural communities whose level of education, financial resources, transport and mobility, computerization, etc. is significantly lower $[20,21,22]$. Rural inhabitants have a level of education far lower than those living in urban areas [23]. Statistically, the lower the socio-economic status of an individual (especially education) the worse their health behaviour [24], as well as the motivation to make changes in their lifestyle, and consequently health [25]. Education is also one of the most important factors affecting the risk of poverty [26]. Considering the place of residence, according to the data published by GUS (the Central Statistical Office) in 2014 regarding the economic poverty in Poland, the level of extreme poverty in rural areas is more than twice as high than in cities. The percentage of rural population in the overall Polish population is $40 \%$, of which $60 \%$ of people live below the extreme poverty [27]. In recent years in Poland, the health status of rural inhabitants has improved in Poland; however, although a clear disproportion between the inhabitants of cities and villages is discernable. According to the 2014 GUS statistics, sport was practiced by every fourth urban inhabitant, while in rural areas it was every seventh. The average time devoted to physical activity by rural inhabitants was twice as short as that spent by urban inhabitants [28]. The differences are also even more evident in the availability of health care, medical centres or participation in prophylactic activities. According to the Report published in 2015 by The European Fund for the Polish Village Development, the number of medical centres in rural areas is more than twice smaller than in the cities (rural areas -3 clinics per 10,000 inhabitants, urban areas - nearly 6.5 clinics per 10,000 inhabitants) [29]. Approximately $14 \%$ of Poles resign from attending appointments and heeding medical advice. The most common reasons for missing an appointment are mainly the long distances to health care facilities, and the fear of high cost of treatment [29]. The health condition of the population is also linked with the environment of life, which include housing conditions. Regarding the households of the elderly, they are less well equipped than the households of young people. Moreover, the households of older rural inhabitants are generally less equipped, compared those living in urban areas. This situation applies to access to basic amenities, such as gas, hot water, bathroom or central heating [30]. The socio-economic situation of the Polish rural inhabitants, together with the progressive aging of the population, could lead to a significant deterioration in their health status in the coming years. It is necessary to assess the level of disability and to conduct a multidimensional analysis for the determining factors among the elderly in rural areas in order to develop systemic solutions to support the health care of this population. The World Health Organization (WHO) has developed (based on the ICF) a high-quality tool for the assessment of disability in order to conduct epidemiological and clinical studies - Disability Assessment Schedule 2.0 (WHODAS 2.0). WHODAS 2.0 has very good psychometric properties [31, 32]. Its usefulness has been confirmed by epidemiological studies carried out in many countries [33]. Therefore, a study using WHODAS enables the researchers to analyze the limitations in the functioning of the elderly and provides guidance for the problems and threats encountered which affect the prevalence of disability and social exclusion. A study of the disability of the elderly in their living environment would be particularly valuable because it could highlight the problems in the functioning in real-life conditions.

\section{MATERIAL AND METHOD}

The study was conducted on a population of 973 people aged 60-80 living in south-eastern Poland (Podkarpacie Region). This group was chosen from a randomly selected and surveyed population of 1,800 people, and the data obtained from the database of the Ministry of Home Affairs and Administration in Poland. The selected group comprised 31,029 people (name, address and PESEL number), including 6,029 people aged $60-70$ and 25,000 aged 71-80. The population of 5,029 and 24,200 people constituted a reserve sample, respectively. The selection for each age group was made using the SPSS software, without returning the already selected participants into the envelope. This method of research provided a high methodological standard and the representative character of the study for the Podkarpackie Region in south-eastern Poland. The assumed confidence level was 95\% (0.95) with the estimation error (maximum error) of 3\%. The study was carried out using direct interview-questionnaires implemented by the Pen and Paper Interviews method. Inclusion criteria were: age 60-80, proper cognitive state (AMTS - abbreviated mental test score $>6$ points), informed consent. The survey was conducted by professional and trained interviewers at the place of residence of the respondents. In accordance with the Declaration of Helsinki, respondents were informed about the purpose and the procedure of the study, and gave their informed consent to participate. The representative nature of the obtained results meant the acquired knowledge could be applied to a large population. The research study was approved by the Bioethical Committee of the University of Rzeszów.

\section{STATISTICAL ANALYSIS}

The obtained data were analyzed by means of StatSoft, Inc. (2011), STATISTICA (data analysis software system), version 10. For the purpose of statistical analysis, basic descriptive statistics were used. Due to the lack of normal distribution of the variables, non-parametric tests were used (the MannWhitney $U$ test and the Kruskal-Wallis test). In the case of statistically significant differences of the results in the compared subsamples, statistical analysis was supplemented by using the multiple comparison method. The level of statistical significance was assumed at $\mathrm{p}<0.05$.

Research tools. The research tool used in the study was the WHO Disability Assessment Schedule (WHODAS 2.0) and a questionnaire including questions concerning sociodemographic data and health in the study group. The WHO Disability Assessment Schedule (WHODAS 2.0) was used to measure health and disability, based on the International Classification of Functioning, Disability and Health (ICF). This measures the level of functioning in six domains of life: Cognition (Domain 1); Mobility (Domain 2); Self-care (Domain 3); Getting along (Domain 4); Life activities domestic responsibilities (Domain 5.1); Participation 
(Domain 6) [31]. Domain 5.2 - work and school - did not regard the study population and; therefore, was not included in the analysis presented in this article.

Particular WHODAS 2.0 domains were linked with the scale ranged from 1-5, where: (1) meant "no" disability problems; (2) - "mild"; (3) - "moderate"; (4) - "severe" and (5) - "extreme" disability. According to the instruction [31], multi-categorial positions were recoded and the original scoring system was converted to the score 0-100. Higher scores indicated more limitations (where $0=$ no difficulty; 100 $=$ extreme difficulties). In order to determine the general level of disability, as well as in particular domains of WHODAS 2.0, the following scale was used (compatible with ICF): no disability $(0-4 \%)$, mild disability $(5-24 \%)$, moderate disability (25-49\%), severe disability (50-95\%), extreme disability (96-100\%) [1]

\section{RESULTS}

The study group included 973 people (549 women and 424 men). The vast majority of the participants were married (68.55\%). Most of the respondents were retired (83.45\%). Almost half of them had primary education (48.41\%). The majority who responded to the question about the level of monthly incomes, declared 2,000 PLN and less per capita/ month (50.57\%). Table 1 presents the basic socio-demographic characteristics of the study group.

Table 2 shows the mean of the results of disability measurements in particular WHODAS 2.0 domains, and the total WHODAS 2.0 score.

As many as $28.26 \%$ of the study group had at least a moderate level of disability, severe disability was observed in $11.51 \%$ of the participant, and extreme disability was experienced by $0.21 \%$ of the population. A moderate level of disability means limitations and obstacles which may limit (to a large extent) proper functioning. An extreme or extremely big problem means a significant limitation or inability to exist independently [1]. People with this level of disability need the assistance of others in daily functioning. The average level of disability in the group measured by WHODAS 2.0 (on a scale of $0-100)$ was $23.27(\mathrm{SD}=21.36)$. The highest average level of disability in the study group was found in the case of performing activities of daily living (mean $=28.94 ; \mathrm{SD}=30.04$ ). Concering this domain, difficulties in performing daily activities were assessed, which were associated with running the household, such as cooking, cleaning, shopping, caring for others and for personal belongings. In this domain, the most common occurrence of severe and extremely high levels
Table 1. Sociodemographic characteristics of the study group

\begin{tabular}{|c|c|c|}
\hline Demographic characteristics $(N=973)$ & Number (N) & Percentage (\%) \\
\hline \multicolumn{3}{|l|}{ 1. Sex } \\
\hline Female & 549 & 56.42 \\
\hline Male & 424 & 43.58 \\
\hline \multicolumn{3}{|l|}{ 2. Age } \\
\hline $60-65$ years old & 313 & 32.17 \\
\hline $66-70$ years old & 234 & 24.05 \\
\hline $71-75$ years old & 222 & 22.81 \\
\hline $76-80$ years old & 204 & 20.97 \\
\hline \multicolumn{3}{|l|}{ 3. Marital status } \\
\hline Bachelor/spinster & 38 & 3.91 \\
\hline Married & 667 & 68.55 \\
\hline Separated/divorced & 13 & 1.34 \\
\hline Widower/widow & 250 & 25.69 \\
\hline Living with a partner & 5 & 0.51 \\
\hline \multicolumn{3}{|l|}{ 4. Status on the job market } \\
\hline Gainful employment & 34 & 3.49 \\
\hline Self-employed, e.g., own business or farm & 15 & 1.55 \\
\hline Housewife & 16 & 1.64 \\
\hline Retired & 812 & 83.45 \\
\hline Not working (due to poor health) & 22 & 2.26 \\
\hline Not working (due to other reasons) & 18 & 1.85 \\
\hline Annuitant & 53 & 5.45 \\
\hline Other & 3 & 0.31 \\
\hline \multicolumn{3}{|l|}{ 5. Education } \\
\hline Primary & 471 & 48.41 \\
\hline Vocational & 262 & 26.93 \\
\hline Secondary comprehensive & 63 & 6.47 \\
\hline Secondary vocational & 127 & 13.05 \\
\hline Tertiary & 50 & 5.14 \\
\hline \multicolumn{3}{|l|}{ 6. Income per capita/month } \\
\hline Up to $1000 \mathrm{PLN} *$ & 120 & 12.33 \\
\hline 1001 PLN-2000 PLN & 372 & 38.24 \\
\hline 2001 PLN-3000 PLN & 107 & 10.99 \\
\hline 3001 PLN-4000 PLN & 42 & 4.32 \\
\hline 4001 PLN and above & 20 & 2.05 \\
\hline No data & 312 & 32.07 \\
\hline
\end{tabular}

"PLN - (Polish zloty) - the official name of the Polish currency

Table 2. Mean results of disability measurements in each WHODAS 2.0 domain

\begin{tabular}{|c|c|c|c|c|c|c|c|c|}
\hline Disability domains & $\begin{array}{l}\text { Mean } \\
\text { score }\end{array}$ & $\begin{array}{l}\text { NHODAS } 2.0 \\
95 \% \mathrm{Cl})\end{array}$ & SD & $\begin{array}{l}\text { None } \\
(\%)\end{array}$ & $\begin{array}{l}\text { Mild } \\
(\%)\end{array}$ & $\begin{array}{l}\text { Moderate } \\
\text { (\%) }\end{array}$ & $\begin{array}{l}\text { Severe } \\
(\%)\end{array}$ & $\begin{array}{l}\text { Extreme high } \\
\text { (\%) }\end{array}$ \\
\hline Domain 1: Cognitive functions & 18.46 & $(17.11-19.82)$ & 21.55 & 40.29 & 31.45 & 14.69 & 13.36 & 0.21 \\
\hline Domain 3: Self-care & 11.26 & $(10.02-12.50)$ & 19.71 & 63.93 & 14.29 & 8.94 & 12.23 & 0.61 \\
\hline Domain 4: Getting along & 22.96 & $(21.36-24.56)$ & 25.48 & 34.12 & 28.26 & 24.87 & 12.33 & 0.42 \\
\hline $\begin{array}{l}\text { Domain 5.1: Life activities - domestic } \\
\text { responsibilities }\end{array}$ & 28.94 & $(27.05-30.83)$ & 30.04 & 37.62 & 13.36 & 24.36 & 20.35 & 4.31 \\
\hline Domain 6: Participation in social life & 28.40 & $(26.93-29.87)$ & 23.29 & 15.01 & 34.53 & 29.39 & 20.55 & 0.52 \\
\hline Total WHODAS 2.0 result & 23.27 & $(21.92-24.61)$ & 21.36 & 21.27 & 38.75 & 28.26 & 11.51 & 0.21 \\
\hline
\end{tabular}


of disability were observed. An extreme level of disability was also observed in the area related to participation in everyday life (mean $=28.40 ; \mathrm{SD}=23.29)$. Within this domain, several aspects were measured, such as participation in local community activities, overcoming barriers and obstacles that occur in the external environment and other issues, for instance, a sense of personal dignity. The third place, in terms of incidence of disability, was the domain concerning the mobility of respondents ( mean $=26.04$; SD $=27.57$ ). In this domain, were rated such activities as standing, walking around the house, going out and long distance walking. The least frequent problems and limitations in the study group were observed in self-care, personal hygiene, dressing, eating and staying home alone (mean $=11.26 ; \mathrm{SD}=19.71$ ).

Table 3 shows the results concerning the relationship between the occurrence of general disability and the selected socio-demographic factors.

Statistically significant relationships were observed between all the analyzed variables. In the group of women, a higher level of disability (mean $=25.22)$ was found than in the group of men $($ mean $=20.7 ; p<0.001)$. The level of disability $(p<0.001)$

Table 3. Sociodemographic factors and disability in the studied population

\begin{tabular}{|c|c|c|}
\hline Demographic characteristics & $\begin{array}{c}\text { Mean WHODAS } 2.0 \\
\text { score }(95 \% \mathrm{Cl})\end{array}$ & $\mathrm{p}$ \\
\hline \multicolumn{3}{|l|}{ 1. Sex } \\
\hline Female & $25.22(23.40-27.04)$ & $<0.001$ \\
\hline Male & $20.73(18.76-22.70)$ & \\
\hline \multicolumn{3}{|l|}{ 2. Age } \\
\hline $60-65$ years old & $12.07(10.28-13.87)$ & $<0.001$ \\
\hline $66-70$ years old & $17.01(14.72-19.30)$ & \\
\hline $71-75$ years old & $29.49(27.03-31.95)$ & \\
\hline $76-80$ years old & $40.84(37.90-43.77)$ & \\
\hline \multicolumn{3}{|l|}{ 3. Marital status } \\
\hline Married/living with partner & $20.04(18.51-21.57)$ & $<0.001$ \\
\hline Single & $30.47(27.96-32.97)$ & \\
\hline \multicolumn{3}{|l|}{ Education } \\
\hline Primary & $27.85(25.82-29.87)$ & $<0.001$ \\
\hline Vocational & $18.74(16.33-21.15)$ & \\
\hline Secondary comprehensive & $19.53(14.52-24.55)$ & \\
\hline Secondary vocational & $18.02(14.80-21.23)$ & \\
\hline Tertiary & $21.87(16.39-27.35)$ & \\
\hline \multicolumn{2}{|l|}{ 4. Income per capita/month } & $<0.001$ \\
\hline Up to $1000 \mathrm{PLN}$ & $28.46(24.33-32.59)$ & \\
\hline 1001 PLN-2000 PLN & $30.30(28.03-32.57)$ & \\
\hline 2001 PLN-3000 PLN & $19.67(16.47-22.86)$ & \\
\hline 3001 PLN-4000 PLN & $21.33(16.01-26.64)$ & \\
\hline 4001 PLN and above & $12.66(7.06-18.27)$ & \\
\hline \multicolumn{3}{|l|}{ 5. Number of diagnosed diseases } \\
\hline 0 & $3.60(1.84-5.35)$ & $<0.001$ \\
\hline $1-2$ & $14.72(12.28-17.15)$ & \\
\hline $3-4$ & $23.14(20.75-25.52)$ & \\
\hline 5 and above & $(29.02-33.10)$ & \\
\hline \multicolumn{3}{|l|}{ 6. Physical activity } \\
\hline No & $25.76(24.24-27.27)$ & $<0.001$ \\
\hline Yes & 11.50 (9.41-13.59) & \\
\hline
\end{tabular}

significantly increased with age and with the number of chronic diseases, although there were significant differences in all pairs of subgroups. Considering the marital status of the respondents, a significantly higher level of disability was found in the group of single people, compared to those living in a partnership $(\mathrm{p}<0.001)$. Additionally, respondents with primary education experienced a higher level of disability than those better educated. Statistically significant differences in the level of disability were observed among respondents with different levels of education, although significant differences concerned respondents with primary and vocational education, as well as those with primary and secondary vocational education. Regarding respondents with incomes of 2,000 PLN (and less) per capita in the household, a higher level of disability was noted, compared to those with higher incomes. Significant differences were found between the following subgroups of respondents (regarding their income per capita/month): those with incomes within the range 0-1,000 PLN and 1,001-2,000 PLN, 0-1,000 PLN and 4,000 PLN and more, 1,001-2,000 PLN and 2,001-3,000 PLN, as well as 1,001-2,000 PLN and 4,001 PLN and more. In the group of physically active respondents (as recommended by the Centres for Disease Control and Prevention - CDC) [34] - who undertook at least 150 minutes of physical activity of moderate intensity during the week and performed strengthening exercises of the major muscle groups at least twice a week, a significantly lower level of disability was noted, compared to those not performing the recommended level of physical activity $(\mathrm{p}<0.001)$.

Table 4 shows the results concerning the relationship between the prevalence of disability in the group of men and women in different age categories.

Table 4. Level of disability in the group of women and men in each age category

\begin{tabular}{|c|c|c|c|c|c|c|c|}
\hline & & Women & & & Men & & \\
\hline Age & $\mathrm{n}$ & $\begin{array}{c}\text { Mean } \\
\text { WHODAS } 2.0 \\
\text { score }(95 \% \mathrm{Cl})\end{array}$ & SD & $\mathrm{n}$ & $\begin{array}{c}\text { Mean } \\
\text { WHODAS } 2.0 \\
\text { score }(95 \% \mathrm{Cl})\end{array}$ & SD & $p$ \\
\hline $60-65$ years & 169 & $\begin{array}{c}13.09 \\
(10.57-15.62)\end{array}$ & 16.62 & 144 & $\begin{array}{c}10.88 \\
(8.30-13.45)\end{array}$ & 15.60 & 0.078 \\
\hline $66-70$ years & 125 & $\begin{array}{c}17.80 \\
(14.80-20.83)\end{array}$ & 17.10 & 109 & $\begin{array}{c}16.10 \\
(12.58-19.63)\end{array}$ & 18.57 & 0.289 \\
\hline $71-75$ years & 136 & $\begin{array}{c}32.30 \\
(29.08-35.51)\end{array}$ & 18.98 & 86 & $\begin{array}{c}25.05 \\
(21.37-28.72)\end{array}$ & 17.14 & 0.009 \\
\hline $76-80$ years & 119 & $\begin{array}{c}42.16 \\
(38.28-46.05)\end{array}$ & 21.40 & 85 & $\begin{array}{c}38.98 \\
(34.43-43.52)\end{array}$ & 21.09 & 0.192 \\
\hline$p$ & & $<0.001$ & & & $<0.001$ & & \\
\hline
\end{tabular}

With regard to both gender groups, i.e. rural males and females, the level of disability increased with age, and statistically significant differences were observed between males and females in all pairs of considered age groups, except those within the range 60-65 and 66-70. In each age category in the group of females, a higher average level of disability was noticed compared to males; however, significant differences were observed only in the age group 71-75 ( $\mathrm{p}=0.009)$.

Table 5 presents analysis of the level of disability in the various WHODAS 2.0 domains among males and females.

Statistically significant differences were found in the level of disability between males and femalesd in all WHODAS 2.0 domains. Significantly higher levels of disability were 
Table 5. Level of disability in particular domains of WHODAS 2.0 in the group of women and men

\begin{tabular}{|c|c|c|c|c|c|}
\hline & Women & & Men & & \\
\hline Age & $\begin{array}{c}\text { Mean } \\
\text { WHODAS } 2.0 \\
\text { score }(95 \% \mathrm{Cl})\end{array}$ & SD & $\begin{array}{c}\text { Mean } \\
\text { WHODAS } 2.0 \\
\text { score }(95 \% \mathrm{Cl})\end{array}$ & SD & $\mathrm{p}$ \\
\hline $\begin{array}{l}\text { Domain 1: Cognitive } \\
\text { functions }\end{array}$ & $\begin{array}{c}19.76 \\
17.95-21.57\end{array}$ & 21.57 & $\begin{array}{c}16.78 \\
14.73-18.83\end{array}$ & 21.44 & 0.003 \\
\hline Domain 2: Mobility & $\begin{array}{c}28.59 \\
26.23-30.94 \\
\end{array}$ & 28.10 & $\begin{array}{c}22.74 \\
20.21-25.28\end{array}$ & 26.54 & $<0.001$ \\
\hline Domain 3: Self-care & $\begin{array}{c}12.33 \\
10.62-14.05\end{array}$ & 20.44 & $\begin{array}{c}9.88 \\
8.10-11.66\end{array}$ & 18.66 & 0.043 \\
\hline $\begin{array}{l}\text { Domain 4: Getting } \\
\text { along }\end{array}$ & $\begin{array}{c}24.83 \\
22.67-26.99 \\
\end{array}$ & 25.78 & $\begin{array}{c}20.54 \\
18.16-22.92 \\
\end{array}$ & 24.91 & 0.003 \\
\hline $\begin{array}{l}\text { Domain 5.1: Life } \\
\text { activities - domestic } \\
\text { responsibilities }\end{array}$ & $\begin{array}{c}31.46 \\
28.90-34.01\end{array}$ & 30.49 & $\begin{array}{c}25.68 \\
22.90-28.47\end{array}$ & 29.16 & 0.002 \\
\hline $\begin{array}{l}\text { Domain 6: Participation } \\
\text { in social life }\end{array}$ & $\begin{array}{c}30.85 \\
28.87-32.83\end{array}$ & 23.62 & $\begin{array}{c}25.23 \\
23.08-27.37\end{array}$ & 22.48 & $<0.001$ \\
\hline
\end{tabular}

found in the group of females in each analyzed domain. Particularly high differences were observed in participation in social life and mobility.

\section{DISCUSSION}

There are over one billion people with disabilities worldwide who represent $15 \%$ of the global population. Considering this group, 2 to 4 percent of people experience significant difficulties in daily functioning [35]. The prevalence of disability increases globally, which is associated with such phenomena as population ageing, increased prevalence of chronic diseases, or the improved quality of the measurement assessment methods used [36].

Strengths of the study. The main advantage of this study is the use of a universal tool for the assessment of disability - the WHODAS 2.0 questionnaire. The data thus obtained are accurate and can be compared with the results of other international research on disability. Results of studies by other researchers indicate the high accuracy and reliability of the WHODAS questionnaire, as well as its appropriate internal coherence $[37,38]$. Good quality of data provide an indispensable background for the development of the foundation for social policy (including health and social security), as well as effective support programmes and the adequate financing of health care. The data obtained in the presented study are important due to the opportunity to recognize the determinants of disability among the elderly inhabitants of rural areas, thereby creating the possibility to eliminate barriers and ensuring equal opportunities of life in the aging society. This is the first such study in Poland, which particularly highlights the level of disability among the population aged 60-80 in rural areas.

Limitations. The research was carried out in south-eastern Poland (Podkarpacie Region); the results, therefore, cannot be referred to the whole territory of Poland. Although the community of elderly people living in rural areas may be similar from many aspects, the sample included in the analysis cannot be considered as representative for the whole country.
Results compared to other studies. Results of own studies confirmed that $39.98 \%$ of rural residents, aged $60-80$, present at least a moderate level of disability, which indicates a high degree of limitations and barriers existing in the functioning of a large number of the elderly rural inhabitants of southeastern Poland. These results are consistent with the results of studies by Biritwum et al. carried out in India, Ghana and Russia [39]. Along with an aging population, the number of disabled and dependent people is increasing [40]. European Union Statistics on Income and Living Conditions (EU-SILC) indicate that $35 \%$ of the Polish population report that they suffer long-term health problems which limit their daily functioning. In Europe, the largest percentage of people who declare such problems come from Finland (46\%) and Estonia (44\%), whereas the lowest percentage of the population reporting this problem come from Bulgaria (19\%), Romania and Luxembourg (20\%) [41]. According to the research by the GUS (The Central Statistical Office), this indicator is higher in Poland and amounts 40\% [28]. Chatterji et al. suggest that the difficulties in performing the basic and complex activities of daily living (ADL and IADL) concern older people in most European countries. They claim that the difficulties for the elderly in performing the basic activities of daily living, are gradually being improved, whereas there is no clear evidence of any reduction in restrictions in involvement in complex activities of daily living [15]. Empirical studies showed various trends over the last several years in the prevalence of functional disability among the elderly. Moreover, Manton et al. [42] pointed out a decrease in the incidence of disability in the United States. Furthermore, Christensen et al. [43] also indicated a decrease in the prevalence of disability in the United Kingdom, Finland, Switzerland and France. On the other hand, a different trend was revealed by PalaciosCeña et al. [44]; in the period from 2000-2007, they found an increase in disability in a group of elderly people in Spain. Additionally, Fuller-Thomson et al. [45] indicated that the functional improvement among American seniors is no longer observed and disability level can grow again.

In the presented study, the highest level of disability and limitations were found in the area of complex activities of daily living (Domain 5.1), including cooking, cleaning, shopping, caring for others and for personal belongings. Subsequently, a very big problem was found in the participation of older people in social life (Domain 6) and mobility (Domain 2). Similar results were obtained by Domnez et al. [46], who demonstrated an level of in activities associated with maintaining household and participation in everyday life. They also indicated that the activities in the field of prevention and health care should be based on assessment of the areas of functioning, and their impact on independence and the activities of daily living of an elderly person. According to the World Health Organization, social activity and functional independence are the most important determinants of "active aging" [47]. Moreover, Lok et al. [48] indicate that disability, social support, religiousness, and the type of the personality have the greatest impact on the health of the elderly, and WHODAS is the best tool to measure the areas of disability.

Analysis of the result of the current study also indicates some variables which had significant influence on the prevalence of disability in the study group. It was found that the incidence of disability increased with the respondents' age, which was also confirmed by the results of other studies $[39,49,50]$. 
The presented findings also confirmed the fact that people with low education and lower incomes were at higher risk of disability. Therefore, education and economic status are important variables determining the risk of functional limitations [51, 52]. There are many studies confirming the statement that co-morbidity is associated with the occurrence of disability [53]. The results of own studies also confirmed this relationship. Additionally, it has been found that the practice of physical activity has a positive effect on the prevention of functional limitations. The meta-analysis performed by Taket al. [54] and the review of Vermeulen and Neyens [55] have shown that physical activity prevents and slows down the ageing of the population, and results in the reduction of the prevalence of disability and independence.

Results of own study showed differences between men and women regarding the level of disability. It was found that the level of disability significantly higher among females than males living in rural areas in south-eastern Poland. Each age category of women living in the countryside presented higher levels of disability, and its prevalence was also higher in all age groups. However, significant differences were observed only in the group aged 71-75. In analyzing disability in particular domains, significantly higher levels of disability were noted among women in each domain. Especially high differences concerned participation in social life and mobility $(\mathrm{p}<0.001)$. Differences in health between males and females are due to both biological and social factors [56]. The studies investigating gender differences in 11 European countries, the United Kingdom and the United States, showed that considering the age category, women were more often exposed to disability and depression than men [57]. Hosseinpoor et al. [58], after analyzing the prevalence of disability in 57 countries, showed, that the difference between the genders in $81 \%$ derive from social conditions, including employment (49\%), education (15\%), marital status (12\%) and economic status at home(4\%). The remaining $19 \%$ regarded the differences related to the age and place of residence. The difference between the genders are especially visible in rural areas, due to the lower incomes and lower education which, according to the current worldwide scientific literature, are highly correlated with disability in the group of older women [59].

\section{CONCLUSIONS}

Important demographic and epidemiological changes that take place on a global scale are accompanied by increasing feminization of the elderly population, due to differences in life expectancy between men and women. These trends need the implementation of appropriate preventive actions that can fulfil the needs of the elderly population.

The results of the presented study can provide some guidance on the subject of disability in the group of older people living in rural areas. An increase in the level of education and popularization of physical activity may be helpful in reducing the prevalence of disability among the elderly living in rural areas. Increasing access to health care, aimed at rapid diagnosis of chronic diseases, treatment and rehabilitation, seems to be a reasonable action for preventing disability in rural areas. The findings of the presented and other studies [39] indicate the possible influence on reducing the level of disability of the elderly population by means of the development of directed methods of prevention and support programmes for the elderly. Priority in this age group should also be given to the elimination of barriers in the home environment and adjustment of the places of residence to the needs of the elderly. These recommendations are consistent with the objectives of the WHO global disability action plan 2014-2021: Better health for all people with disability [60].

\section{REFERENCES}

1. World Health Organization. ICF: International Classification of Functioning, Disability and Health. Geneva, WHO; 2001.

2. Kremers SP, de Bruijn GJ, Visscher TL, van Mechelen W, de Vries NK, Brug J. Environmental influences on energy balance-related behaviors: a dual-process view. Int J BehavNutr Phys Act. 2006; 3: 9.

3. Whiteneck G. Conceptual models of disability: past, present, and future. In: Field MJ, Jette AM, Martin L, editors. Workshop on disability in America: a new look. DC: The National Academies Press, Washington; 2006. p. $50-66$.

4. Levasseur M, Richard L, Gauvin L, Raymond E. Inventory and analysis of definitions of social participation found in the aging literature: proposed taxonomy of social activities. SocSci Med. 2010; 71:2141-2149.

5. Adams KB, Leibbrandt S, Moon H. A critical review of the literature on social and leisure activity and wellbeing in later life. Aging \& Society. 2011; 31(4): 683-712.

6. Berkman LF, Glass T, Brissette I, Seeman TE. From social integration to health: Durkheim in the new millennium. SocSci Med. 2000; 51(6): 843-857.

7. Cohen S. Social relationships and health. Am Psychol. 2004; 59(8): 676-84.

8. Smith KP, Christakis NA. Social networks and health. Annu Rev Sociol. 2008; 34: 405-429.

9. Emmons KM, Barbeau EM, Gutheil C, Stryker JE, Stoddard AM. Social influences, social context, and health behaviors among working-class, multi-ethnic adults. Health EducBehav. 2007; 34(2): 315-34.

10. Bot S, Mackenbach J, Nijpels G, Lakerveld J. Association between Social Network Characteristics and Lifestyle Behaviours in Adults at Risk of Diabetes and Cardiovascular Disease. Plos One. 2016; 11(10): e0165041.

11. Dickens AP, Richards SH, Greaves CJ, Campbell JL. Interventions targeting social isolation in older people: a systematic review. BMC Public Health. 2011; 11: 647.

12. Kono A, Kai I, Sakato C. Frequency of going outdoors: a predictor of functional and psychosocial change among ambulatory frail elders living at home. J Gerontol A BiolSci Med Sci. 2004; 59: 275-280.

13. Fiske A, Wetherell JL, Gatz M. Depression in Older Adults. Annu Rev Clin Psychol. 2009; 5: 363-389.

14. Barnett K, Mercer SW, Norbury M, Watt G, Wyke S, Guthrie B. Epidemiology of multimorbidity and implications for health care, research, and medical education: a cross-sectional study. Lancet. 2011; 380: 37-43.

15. Chatterji S, Byles J, Cutler D, Seeman T, Verdes E. Health, functioning, and disability in older adults--present status and future implications. Lancet. 2015; 385(9967): 563-75.

16. Lally F, Crome P. Understanding frailty. Postgrad Med J. 2007; 83: $16-20$.

17. Gupta P, Mani K, Rai SK, Nongkynrih B, Gupta SK. Functional disability among elderly persons in a rural area of Haryana. Indian J Public Health. 2014; 58(1): 11-6.

18. Levasseur M, Gauvin L, Richard L, Kestens Y, Daniel M, Payette H, et al. Associations between perceived proximity to neighborhood resources, disability, and social participation among community-dwelling older adults: results from the VoisiNuAge study. Arch Phys Med Rehabil. 2011; 92: 1979-1986.

19. Holt-Lunstad J, Smith TB, Baker M, Harris T, Stephenson D. Loneliness and social isolation as risk factors for mortality: a meta-analytic review. Perspect Psychol Sci. 2015; 10(2): 227-237.

20. Grosse TG, Hardt Ł. Sektorowa czy zintegrowana, czyli o optymalnej strategii rozwoju polskiej wsi. Pro Oeconomia Fundacja Ewaluacji i Badań Ekonomicznych. KeyText, Warszawa; 2013.

21. Czapiński J, Panek T. Diagnoza społeczna. Warunki i jakość życia Polaków. Rada Monitoringu Społecznego, Warszawa; 2009. 
22. Heffner K, Klemens B. Warunki życia i aktywność społecznogospodarcza mieszkańców na obszarach wiejskich (na przykładzie województwa opolskiego). Barometr Regionalny. 2012; 4(30): 81-88.

23. Główny Urząd Statystyczny. Wyniki Narodowego Spisu Powszechnego Ludności i Mieszkań 2011. Podstawowe informacje o sytuacji demograficzno - społecznej ludności Polski oraz zasobach mieszkaniowych. GUS, Warszawa; 2012.

24. Marmot M, Friel S, Bell R, Houweling TA, Taylor S, Commission on Social Determinants of Health. Closing the gap in a generation: health equity through action on the social determinants of health. Lancet. 2008; 372(9650): 1661-9.

25. Korzeniowska E, Puchalski K. Niskowykształceni pracownicy a zdrowie - wyzwania dla edukacji zdrowotnej. LEECH, RīgaStradiņš University; 2010.

26. Eurostat. People at risk of poverty or social exclusion. http://ec.europa. eu/eurostat/statistics-explained/index.php/People_at_risk_of_ poverty_or_social_exclusion (access: 2016.11.26).

27. Główny Urząd Statystyczny. Ubóstwo ekonomiczne w Polsce w 2014 r. GUS, Warszawa; 2015.

28. Główny Urząd Statystyczny. Stan zdrowia ludności Polski w 2014r. GUS, Warszawa; 2016.

29. Tyszka S, Solon-Lipiński M. Stan zdrowia ludności wiejskiej w Polsce. Forum Inicjatyw Rozwojowych Fundacji Europejski Fundusz Rozwoju Wsi Polskiej, Warszawa; 2015.

30. Błędowski P, Szatur-Jaworska B, Szweda-Lewandowska Z, Kubic P. Raport na temat sytuacji osób starszych w Polsce. Instytut Pracy i Spraw Socjalnych Warszawa, Warszawa; 2012.

31. Üstün TB, Kostanjsek N, Chatterji S, Rehm J. Measuring Health and Disability Manual for WHO Disability Assessment Schedule WHODAS 2.0. WHO, Geneva; 2010.

32. Üstün TB, Chatterji S, Kostanjsek N, Rehm J, Kennedy C, EppingJordan J, et al. Developing the world health organization disability assessment schedule 2.0. WHO. 2010; 88: 815-823.

33. Harttgen K, Kowal P, Strulik H, Chatterji S, Vollmer S. Patterns of frailty in older adults: comparing results from higher and lower income countries using the Survey of Health, Ageing and Retirement in Europe (SHARE) and the Study on global AGEing and adult health (SAGE). PLoS One 2013; 8(10); e75847.

34. Centers for Disease Control and Prevention. Physical activity for everyone: guidelines: older adults. Physical Activity for Everyone Web site. https://www.cdc.gov/physicalactivity/basics/older_adults/index. htm (access: 2016.12.06).

35. World Health Organization, The World Bank: World Report on Disability. WHO, Geneva; 2011. p. 350.

36. Downing NR, Kim JI, Williams JK, Long JD, Mills JA, Paulsen JS, et al. WHODAS 2.0 in prodromal Huntington disease: measures of functioning in neuropsychiatric disease. Eur J Hum Genet. 2014; 22: 958-963.

37. Silva C, Coleta I, Silva AG, Amaro A, Alvarelhao J, Queiros A, et al. Adaptation and validation of the WHODAS 2.0 in patients with musculoskeletal pain. Rev SaudePublica. 2013; 47: 1-6.

38. Murray CJ, Vos T, Lozano R, Naghavi M, Flaxman AD, Michaud C, et al. Disability-adjusted life years (DALYs) for 291 diseases and injuries in 21 regions, 1990-2010: a systematic analysis for the Global Burden of Disease Study 2010. Lancet. 2012; 380(9859): 2197-223.

39. Biritwum RB, Minicuci N, Yawson AE, Theou O, Mensah GP, Naidoo $\mathrm{N}$, et al. Prevalence of and factors associated with frailty and disability in older adults from China, Ghana, India, Mexico, Russia and South Africa. Maturitas. 2016; 91: 8-18.

40. Senior HE, Parsons M, Kerse N, Chen MH, Jacobs S, Hoorn SV, et al. Promoting independence in frail older people: a randomised controlled trial of a restorative care service in New Zealand. Age Ageing. 2014; 43(3): 418-424.

41. Lacovou M, Kaminska O, Levy H. Using EU-SILC data for crossnational analysis: strengths, problems and recommendations. Instytute for Social and Economic Research, Essex University; 2012.
42. Manton KG, Gu X, Lowrimore GR. Cohort changes in active life expectancy in the U.S. elderly population: Experience from the 19822004 National Long-Term Care Survey.J Gerontol B Psychol SciSocSci. 2008; 63: 269-281.

43. Christensen K, Doblhammer G, Rau R, Vaupel JW. Ageing populations: The challenges ahead. Lancet. 2009; 374: 1196-1208.

44. Palacios-Ceña D, Jiménez-García R, Hernández-Barrera V, AlonsoBlanco C, Carrasco-Garrido P, Fernández-de-Las-Peñas C. Has the prevalence of disability increased over the past decade (2000-2007) in elderly people? A Spanish population-based survey. J Am Med Dir Assoc. 2012; 13(2): 136-42.

45. Fuller-Thomson E, Yu B, Nuru-Jeter A, Guralnik JM, Minkler M. Basic ADL disability and functional limitation rates among older Americans from 2000-2005: The end of the decline? J Gerontol A BiolSci Med Sci. 2009; 64: 1333-1336.

46. Donmez L, Gokkoca Z, Dedeoglu N. Disability and its effects on quality of life among older people living in Antalya city center, Turkey. Arch GerontolGeriatr. 2005; 40(2): 213-23.

47. World Health Organization. Active ageing: a policy framework. http:// whqlibdoc.who.int/hq/2002/WHO_NMH_NPH_02.8.pdf (access: 2016.12.08).

48. Loke SC, Abdullah SS, Chai ST, Hamid TA, Yahaya N. Assessment of factors influencing morale in the elderly. PLoS One. 2011; 256(1): e16490.

49. Mahesh M, Abdin E, Vaingankar JA, Picco L, Jeyagurunathan A, Shafie SB, et al. Ann Acad Med Singapore. 2016; 45: 284-96.

50. Guralnik JM, Ferrucci L, Simonsick EM, Salive ME, Wallace RB. Lowerextremity function in persons over the age of 70 years as a predictor of subsequent disability. N Engl J Med. 1995; 332: 556-561.

51. Amaducci L, Maggi S, Langlois J, Minicuci N, Baldereschi M, Di Carlo A, et al. Education and the risk of physical disability and mortality among men and women aged 65 to 84: the Italian Longitudinal Study on Aging. J Gerontol A BiolSci Med Sci. 1998; 53(6): M484-90.

52. Mondal MN, Shitan M. Relative importance of demographic, socioeconomic and health factors on life expectancy in low- and lowermiddle-income countries. J Epidemiol. 2014; 24(2): 117-24.

53. McDaid O, Hanly MJ, Richardson K, Kee F, Kenny RA, Savva GM. The effect of multiple chronic conditions on self-rated health, disability and quality of life among the older populations of Northern Ireland and the Republic of Ireland: a comparison of two nationally representative cross-sectional surveys. BMJ. 2013; 3(6): e002571.

54. Tak E, Kuiper R, Chorus A, Hopman-Rock M. Prevention of onset and progression of basic ADL disability by physical activity in community dwelling older adults: a meta-analysis. Ageing Res Rev. 2013; 12(1): 329-38.

55. Vermeulen J, Neyens J. Predicting ADL disability in communitydwelling elderly people using physical frailty indicators: a systematic. BMC Geriatr. 2011; 11: 33.

56. Blas E, Kurup AS. Equity, social determinants and public health programmes. WHO, Geneva; 2010. p. 303.

57. Crimmins EM, Kim JK, Solé-Auró A. Gender differences in health: results from SHARE, ELSA and HRS. The Eur J Public Health. 2011; 21(1): 81-91.

58. Hosseinpoor AR, Williams JS, Jann B, Kowal P, Officer A, Posarac A, et al. Social determinants of sex differences in disability among older adults: a multi-country decomposition analysis using the World Health Survey. Int J Equity Health. 2012; 11: 52.

59. Huisman M, Kunst AE, Mackenbach JP. Socioeconomic inequalities in morbidity among the elderly; a European overview. SocSci Med. 2003; 57: 861-873.

60. World Health Organization. WHO global disability action plan 20142021: Better health for all people with disability. http://apps.who.int/ iris/bitstream/10665/199544/1/9789241509619_eng.pdf?ua=1 (access: 2016.12.08). 